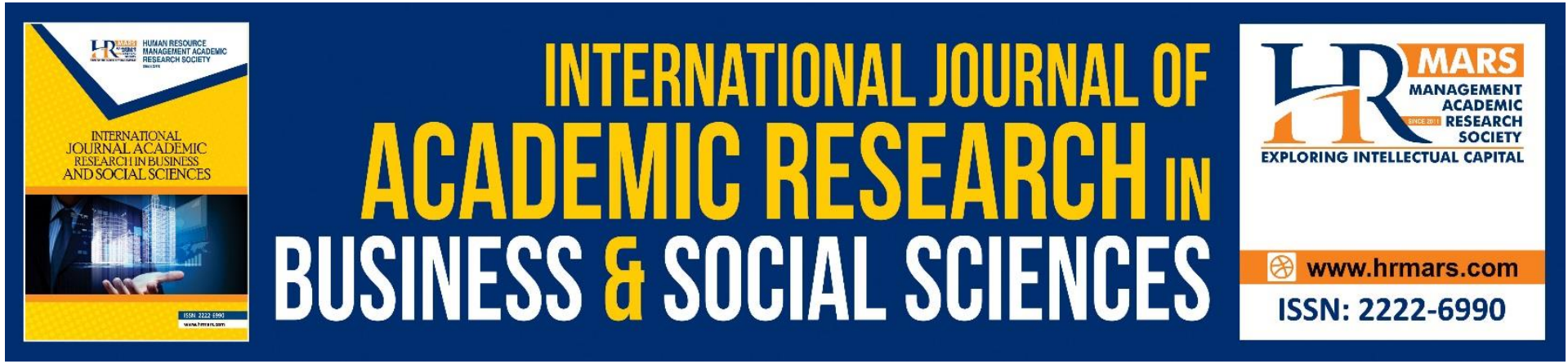

\title{
Self-efficacy, Motivation, Learning Strategy and Their Impacts on Academic Performance
}

Nur Syaliza Hanim Che Yusof, Nor Fatihah Abd Razak, Noor llanie Nordin, Siti Nurani Zulkfli

To Link this Article: http://dx.doi.org/10.6007/IJARBSS/v11-i9/11028

DOI:10.6007/IJARBSS/v11-i9/11028

Received: 06 July 2021, Revised: 29 July 2021, Accepted: 20 August 2021

Published Online: 14 September 2021

In-Text Citation: (Yusof et al., 2021)

To Cite this Article: Yusof, N. S. H. C., Razak, N. F. A., Nordin, N. I., \& Zulkfli, S. N. (2021). Self-efficacy, Motivation, Learning Strategy and Their Impacts on Academic Performance. International Journal of Academic Research in Business and Social Sciences, 11(9), 451-457.

Copyright: @ 2021 The Author(s)

Published by Human Resource Management Academic Research Society (www.hrmars.com)

This article is published under the Creative Commons Attribution (CC BY 4.0) license. Anyone may reproduce, distribute, translate and create derivative works of this article (for both commercial and non-commercial purposes), subject to full attribution to the original publication and authors. The full terms of this license may be seen at: http://creativecommons.org/licences/by/4.0/legalcode

Vol. 11, No. 9, 2021, Pg. 451 - 457

Full Terms \& Conditions of access and use can be found at http://hrmars.com/index.php/pages/detail/publication-ethics 


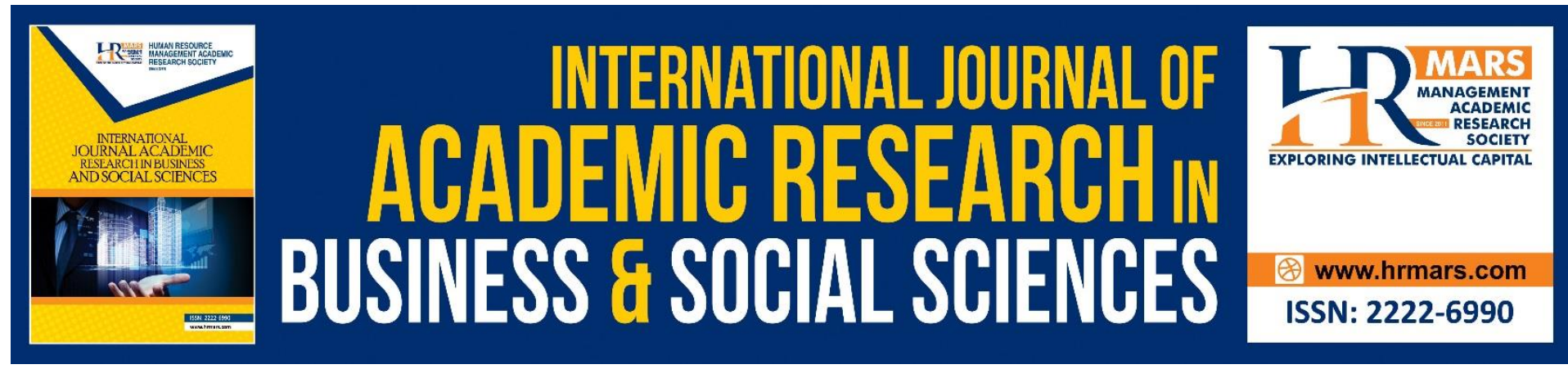

\title{
Self-efficacy, Motivation, Learning Strategy and Their Impacts on Academic Performance
}

\author{
Nur Syaliza Hanim Che Yusof, Nor Fatihah Abd Razak, Noor \\ Ilanie Nordin, Siti Nurani Zulkfli \\ Faculty of Computer and Mathematical Sciences, Universiti Teknologi MARA, Malaysia \\ Email: syaliza648@uitm.edu.my,nfatih570@uitm.edu.my, ilanie@uitm.edu.my, \\ nurani08@uitm.edu.my
}

\begin{abstract}
Psychological factors are widely being studied as one of the prominent factors in academic performance. The present study aims to focus on exploring self-efficacy, motivation and learning strategy in determining the academic performance of Malaysian undergraduate students. A set of structured questionnaires were distributed to undergraduate students from a public university located in East Coast of Malaysia which was selected through stratified sampling technique. data was analyzed by using SPSS software. Pearson Correlation Coefficient was used to determine the association between age, self-efficacy score, motivation, and learning strategy with academic performance. The findings show that academic performance has the highest correlation with age and learning strategy but lowest correlation with self-efficacy score. Moreover, motivation and learning strategy are significantly positive correlation while age is significantly negative correlation with academic performance. Based on multiple linear regression analysis, this study identified that age and learning strategy have significant effects in predicting academic performance. This study contributes to the awareness of knowledge in learning strategy for lecturers and students in adapting proper learning methods to maximize learning outcomes.
\end{abstract}

Keywords: Self-efficacy, Motivation, Learning Strategy, Age, Academic Performance

\section{Introduction}

Academic performance has been the main area of interest for higher education institutions not only in Malaysia but also worldwide where researchers and educators continue investigating the factors that are related to academic performance. Consideration has been given to how to maximize learners' academic performance or learning outcomes so that the dropout rates will get lessen. In educational psychology, attention has been given to selfefficacy as a prominent factor to enhance academic performance (Klassen \& Usher, 2010; Vuong, Brown-Welty \& Tracz, 2010; Dogan, 2015). The concept of self-efficacy refers to individuals' own beliefs about their capabilities to organize and execute the courses of action to produce different levels of performance (Bandura, 1997). Within an academic context, Elias \& MacDonald (2007) stated self-efficacy can be also described as academic self-efficacy which defines learner judgments on their abilities to successfully achieve educational goals. Loo \& 
Choy (2013) study on sources of self-efficacy (mastery experience, vicarious experience, social persuasion, emotional arousal) that correlated with academic achievements of mathematics that related with engineering modules of college student in Singapore found out that mastery experience was the main predictor for academic achievement. This indicates that mastery in experience may drive the future better in academic performance.

Besides self-efficacy, motivation has also been reported as a significant factor on academic performance in a recent study by Kumar \& Tankha (2020). According to Herzberg's (1959) theory, motivation can also drive people to perform better in his or her task. The theory assumed that motivators are linked with long-time positive effects in performance. Elias, Mustafa, Roslan \& Noah (2011) in their study stated that motivation is student main priority where they will put more effort forcing themselves to complete the task persistently and this may lead them to achieve their target progressively. This indicates that motivation also plays a part in students' academic achievement. On the other hand, learning strategies also had been extensively deliberated within educational psychology literature where students with their preferred learning strategy would learn the content better. To support this, Yip (2013) found that there is a significant difference in learning strategy between high and low academic achievers in influencing academic performances at tertiary level. Learning strategy or learning styles is defined as how students deal with their study approaches through their surroundings and how they can adapt the task given in order to produce good results (Richardson, 2011). Chen (2009) study also found that there was a significant relationship between the grade rank and language learning strategies.

Malaysian researchers have recently broadened their study on psychological impact of academic performance, some psychological factors which have found to have significant connection with academic performance in tertiary level includes emotional intelligence, achievement motivation, self-efficacy and self-regulated learning strategies (Mahyuddin, Elias \& Noordin, 2009; Elias, Mustafa, Roslan \& Noah, 2011; Yusuf, 2011; Amin, Hassan \& Jalil, 2018). To understand the impact better, this present study focuses on exploring the significance of three psychological factors (self-efficacy, motivation and learning strategy) and also added the impact of demographic factor which is age in determining the academic performance of Malaysian undergraduate students.

\section{Method}

The total undergraduate students from a public university located in the East Coast of Malaysia are 757 students. Then, using Raosoft software the minimum recommended sample size is 256 students. This study employed stratified sampling where the strata or groups classified based on their programs enrolled which are Bachelor in Marketing, Bachelor in Statistics and Bachelor in Finance, Bachelor in Islamic Banking. To avoid low percentage in response rate, this study distributed a total of 290 sets of questionnaires and 276 completed questionnaires were analyzed. Data were collected using structured questionnaires for one semester period starting January to March where respondents were approached in their class. The structured questionnaire consists of four sections which are demographic profile for Section A where academic performance as indicator measured in Grade Point Average (GPA) for current semester, self-efficacy for Section B, motivation for Section C and learning strategy for Section D. General Self-Efficacy (GSE) scale with 10 items was adopted from Schwarzer \& Jerusalem (1995) with 4-point scale ranging from 1 (not at all true) to 4 (exactly true). The total score is calculated by sum of all 10 items and a total score with a higher score 
indicates more self-efficacy. Meanwhile, motivation and learning strategy scale adapted from Pintrich, Smith, Garcia \& Mckeachie (1993) with 7-point scale ranging from 1 (strongly disagree) to 7 (strongly agree). The Cronbach's alpha in this study was $0.788,0.866$ and 0.704 for general self-efficacy, motivation, and learning strategy, respectively.

Data were analyzed using SPSS where demographic of the participants which are age and GPA were expressed as mean. Moreover, Pearson correlation coefficients were used to investigate the association between all three psychological factors and academic performance. A multivariate regression analysis using the Enter method was then carried out to examine demographic variables (age) and psychological variables (self-efficacy, motivation, and learning strategy) as predictors of academic performance. The significance level for all tests was $p<0.05$. Before that, all assumptions for regression analysis were fulfilled where there is normality of dependent variables, no multicollinearity between predictors and lastly homoscedasticity of the residuals.

\section{Results and Discussion}

Table 1 represents the descriptive statistics (mean and standard deviation) together with Pearson correlation coefficient for all variables in this study including age as demographic variable. Average of academic performance which is 3.34 indicates that participants are good academic achiever. Table 1 shows that academic performance has the highest correlation with age and learning strategy but lowest correlation with self-efficacy score. Besides, only self-efficacy score did not significantly correlate with academic performance while other factors (age, motivation and learning strategy) are significantly associated with academic performance. Motivation and learning strategy show significantly positive correlation while age is significantly negative correlation with academic performance. This means that as they get older in university, their performance decreases. These findings contradict with the study done by Nasir (2012) who found a significant positive correlation of age with academic performance. The significant positive correlation in motivation and academic performance indicates that students with high motivation can achieve good grades rather than students who have low motivation.

TABLE 1: Descriptive Statistics and Correlation Coefficients for Variables

\begin{tabular}{llllllll}
\hline & Variables & Mean & SD & 1 & 2 & 3 & 4 \\
\hline 1 & Age & 21.84 & 0.895 & 1 & & & \\
\hline 2 & $\begin{array}{l}\text { Self-efficacy } \\
\text { score }\end{array}$ & 34.72 & 3.308 & 0.095 & & & \\
\hline 3 & Motivation & 5.10 & 0.997 & $0.123^{*}$ & $\begin{array}{l}0.244^{*} \\
*\end{array}$ & & \\
\hline 4 & $\begin{array}{l}\text { Learning } \\
\text { Strategy }\end{array}$ & 4.62 & 0.624 & 0.073 & $0.224^{*}$ & $0.500^{* *}$ & \\
\hline 5 & $\begin{array}{l}\text { Academic } \\
\text { Performance }\end{array}$ & 3.34 & 0.348 & $-0.236^{* *}$ & 0.101 & $0.186^{* *}$ & $0.234^{* *}$ \\
& & & & & & & \\
\hline
\end{tabular}

Note: $\mathrm{N}=276 ;{ }^{*} \mathrm{p}<0.05 ;{ }^{* *} \mathrm{p}<0.01$

The results of multivariate regression analysis using Enter method in Table 2 showed that the model is significant $\left(R=0.365, R^{2}=0.133, F=10.419, p<0.01\right)$ with $13.3 \%$ variation in academic performance can be explained by age, self-efficacy score, motivation and learning strategy. 
Table 2 indicates that only two variables are age and learning strategy that significantly predict academic performance.

TABLE 2: Multiple Regression Analysis for Predicting Academic Performance

\begin{tabular}{llll}
\hline Variables & B & Std. Error & t-statistics value \\
\hline Constant & 4.741 & 0.515 & 9.214 \\
\hline Self-efficacy score & 0.006 & 0.006 & 0.973 \\
\hline Motivation & 0.040 & 0.023 & 1.710 \\
\hline Learning Strategy & 0.102 & 0.037 & $2.791^{* *}$ \\
\hline Age & -0.105 & 0.022 & $-4.707^{* *}$ \\
\hline
\end{tabular}

Note: $* * p<0.01$

Consistent with previous research findings, the result of multiple regression analysis found out learning strategy as a significant predictor of academic performance (Pintrich, 2004). Thus, this study reveals that students' academic performance significantly depends on their learning strategies for different tasks and contexts. Nasiri, Gharekhani \& Ghasempour (2016) found that there was a significant relationship between visual learning style preference and the mean score of students' final exam. This supported the findings that students who have learning strategies with the correct contents may perform better than students who do not have any learning strategies in study. Academic performance can be measured for any student by its home environment as well as their learning skills (Shahzadi \& Ahmad, 2011). Their predictive model stated that students can achieve high academic performance by focus only on the home environment and their learning skills.

This study also found age as a demographic factor that significantly associated with academic performance. It was consistent with the findings by another study (Momanyi, Too \& Simiyu, 2015) that shows the youngest students had the highest mean score while the oldest students had the lowest mean score in academic performance. It indicates that the youngest students perform better than oldest students in performance. Clark and Ramsay (1990) also detected a negative relationship between age and academic performance. These findings indicate that the ideal age for an undergraduate to perform better is ranging $21-25$ years, while when getting older understanding in areas of study getting slower thus affect the academic performance.

\section{Conclusion}

Based on the findings, this study revealed that there is a significant relationship of age and learning strategy with the academic performance of undergraduate students. It is crucial to be aware of knowledge of learning strategy for a student since with this knowledge the student is better able to understand their preferences and learning strategy as their advantage to maximize learning outcomes. Besides, students usually have preferences in the ways they learn or understand a subject and it is advisable for students to find their styles in order to suit their own learning needs. These findings also revealed that age is one of the factors that is also significantly associated with academic performance and was supported by previous research done by Momanyi, Too \& Simiyu (2015) as well as Clark and Ramsay (1990). This indicates that the ideal age for undergraduate students is ranging 21 to 25 years. Who in this age is suitable to study and perform well in their course or subject field. For the future study, the researcher was recommended to extend the study that covered undergraduate 
students from a public university located in West Coast of Malaysia and private university in Malaysia.

\section{References}

Amin, I. M. H., Hassan, N. C., \& Jalil, H. A. (2018). Predictors of Academic Achievement in Online Peer Learning among Undergraduate Students in a Malaysian Public University. International Journal of Academic Research in Business and Social Sciences, 7(14).

Bandura, A. (1997). Self-Efficacy: The Exercise of Control (1st ed.). Worth Publishers.

Chen, M. L. (2009). Influence of grade level on perceptual learning style preferences and language learning strategies of Taiwanese English as a foreign language learners. Learning and Individual Differences, 19(2), 304-308.

Clark, E. E., \& Ramsay, W. (1990). Problems of retention in tertiary education. Education Research and Perspectives, 17(2), 47-57.

Dogan, U. (2015). Student Engagement, Academic Self-efficacy, and Academic Motivation as Predictors of Academic Performance, The Anthropologist, 20(3), 553-561.

Elias, H., Mustafa, S. M. S., Roslan, S., \& Noah, S. M. (2011). Motivational Predictors of Academic Performance in End Year Examination. Procedia - Social and Behavioral Sciences, 29, 1179-1188.

Elias, S. M., \& MacDonald, S. (2007). Using Past Performance, Proxy Efficacy, and Academic Self-Efficacy to Predict College Performance. Journal of Applied Social Psychology, 37(11), 2518-2531.

Herzberg, F., Mausner, B., \& Synderman, B. B. (1959). The Motivation to Work (2nd ed). John Wiley \& Sons.

Klassen, R. M., \& Usher, E. L. (2010). Self-efficacy in educational settings: Recent research and emerging directions. The decade ahead: Theoretical perspectives on motivation and achievement.

Kumar, V. V., \& Tankha, G. (2020). Influence of Achievement Motivation and Psychological Adjustment on Academic Achievement: A Cross-Sectional Study of School Students. Humanities \& Social Sciences Reviews, 8(1), 532-538.

Loo, C., \& Choy, J. (2013). Sources of Self-Efficacy Influencing Academic Performance of Engineering Students. American Journal of Educational Research, 1(3), 86-92.

Mahyuddin, R., Elias, H., \& Noordin, N. (2009). Emotional Intelligence, Achievement Motivation and Academic Achievement Among Students of the Public and Private Higher Institutions. The International Journal of Diversity in Organizations, Communities, and Nations: Annual Review, 9(4), 135-144.

Momanyi, J. M., Too, J., \& Simiyu, C. (2015). Effect of students' age on academic motivation and academic performance among high school students in Kenya. Asian Journal of Education and E-Learning, 3(5), 337-342.

Nasir, M. (2012). Demographic characteristic as correlates of academic achievement of university students. Academic Research International, 2(2), 400.

Nasiri, Z., Gharekhani, S., \& Ghasempour, M. (2016). Relationship between learning style and academic status of Babol dental students. Electronic physician, 8(5), 2340.

Pintrich, P. R. (2004). A conceptual framework for assessing motivation and self-regulated learning in college students. Educational Psychology Review, 16(4), 385-407.

Pintrich, P. R., Smith, D. A. F., García, T., \& Mckeachie, W. J. (1993). Reliability and Predictive Validity of the Motivated Strategies for Learning Questionnaire (MSLQ). Educational and Psychological Measurement, 53(3), 801-813. 
Remali, A. M., Ghazali, M. A., Kamaruddin, M. K., \& Kee, T. Y. (2013). Understanding academic performance based on demographic factors, motivation factors and learning styles. International journal of Asian social science, 3(9), 1938-1951.

Richardson, J. T. (2011). Approaches to studying, conceptions of learning and learning styles in higher education. Learning and Individual Differences, 21(3), 288-293.

Schwarzer, R., \& Jerusalem, M. (1995). Generalized Self-Efficacy scale. In J. Weinman, S. Wright, \& M. Johnston (Eds.), Measures in health psychology: A user's portfolio. Causal and control beliefs (pp. 35-37). Windsor, England: NFER-NELSON.

Shahzadi, E., \& Ahmad, Z. (2011). A Study on Academic Performance of University Students. Recent Advances in Statistics, 255.

Vuong, M., Brown-Welty, S., and Tracz, S. (2010). The effects of self-efficacy on academic success of first-generation college sophomore students. Journal of college student development, 51(1), 50-64.

Yip, M. C. (2013). Learning strategies and their relationships to academic performance of high school students in Hong Kong. Educational Psychology, 33(7), 817-827.

Yusuf, M. (2011). The impact of self-efficacy, achievement motivation, and self-regulated learning strategies on students' academic achievement. Procedia-Social and Behavioral Sciences, 15, 2623-2626. 